\title{
海面埋立地内水面の水質環境とプランクトン組成の変動
}

\author{
山田真知子, 花田喜文, 末田新太郎, 鶴田新生, 吉田陽一 \\ (1989 年 10 月 16 日受村)
}

\author{
Change of Water Quality and Composition of Plankton in the \\ Pond of Reclaimed Site \\ Machiko Yamada,*1 Yoshifumi Hanada, ${ }^{* 1}$ Shintaro Sueta,*1 \\ Arao Tsuruta, ${ }^{* 2}$ and Yoichi Yoshida*3
}

\begin{abstract}
In order to obtain some fundamental data for maintenance of the coastal reclaimed site for disposal of various solid wastes, change of plankton population were investigated in relation to the change of water quality in a reclaimed site pond formed along the coastal line of Kitakyushu City, Japan. The pond water became rapidly brackish and polluted during seven years needed for the completion of the reclamation by disposing of the solid wastes.

The water quality in this pond was arranged in five clusters by use of one numerical classification method, agglomerative cluster analysis, which employs four water factors: $\mathrm{pH}$, chlorinity, suspended solids, and COD on four seasons: February in winter, May in spring, August in summer, and Novernber in autumn.

The occurrence pattern of dominant phytoplankton and five clusters of water quality were compared; it was found that the alternation between marine plankton and brackish-water plankton was observed around $10 \%$ in chlorinity, and fresh-water plankton began to appear below $5 \%$ in chlorinity. The marine plankton's highest COD value was $17 \mathrm{mg} / l$, and freshand brakish water forms were able to occur as high as $40 \mathrm{mg} / \mathrm{l}$ in COD. One species of a phototrophic bacterium was observed in one cluster which had abnormal conditions of 160 $\mathrm{mg} / \mathrm{l}$ in $\mathrm{COD}$ and 11.2 in $\mathrm{pH}$.

These results revealed that there was an intimate relation between the characteristic occurrence of plankton and water quality in each of the five clusters. The appearance of planktonic biota and the variation of water quality were affected by the climatic conditions, such as rises of temperature and copious rainfall.
\end{abstract}

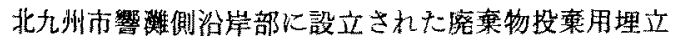
地内水面では約 7 年にわたる埋め立ての問，細菌㧍よび 動，植物プランクトンの各種が遷移しながら多量飞出現 した。これらの生物群は本内本面で酸化池的機能を不十

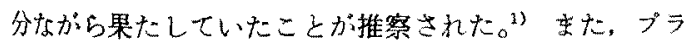
ンタトンが内水面の水質を示すハイオメーターとして利 用できる可能性のあることも示㙏された。

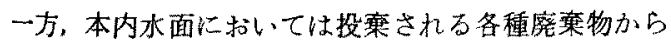
海水中に COD 成分や䇪素、リンなどが溶出当ることが

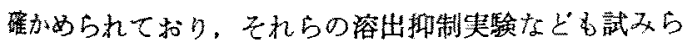
れている。名)そこで，本報では今後增加の予想される海
面埋立地")の維持管理のための基礎資料を得ることを目 的之して。本内水面について，ブランクトン調查之，同 時比実施さ扎大理化学的水質調查精果を㭘討士るととも

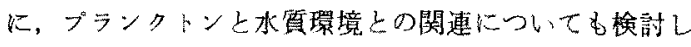
た。

\section{調查 方 法}

埋立地の概要战よびプランタトン調查の方法は前報” で述べたと㧍りである。

水質の理化学的測定は.プランクトン調查と同し調查 地点の午前 9 時から 10 時の間倸取した表層水 $(20$

*1 北九州市謤境衛生研究可 (Kitakyushu Municipal Institute of Environmental Health Sciences, Kitakyushu 804, Japan).

*2 水亷大学校增殖学科 (Department of Aquaculture and Biology, Shimonoseki University of Fisheries, Shimonoseki 759-65, Japan).

*3 京都大学大学院農学研究科熱带農学禁攻 (Division of Tropical Agriculture, Graduate School of Agriculture, Kyoto University, Kyoto 606, Japan). 


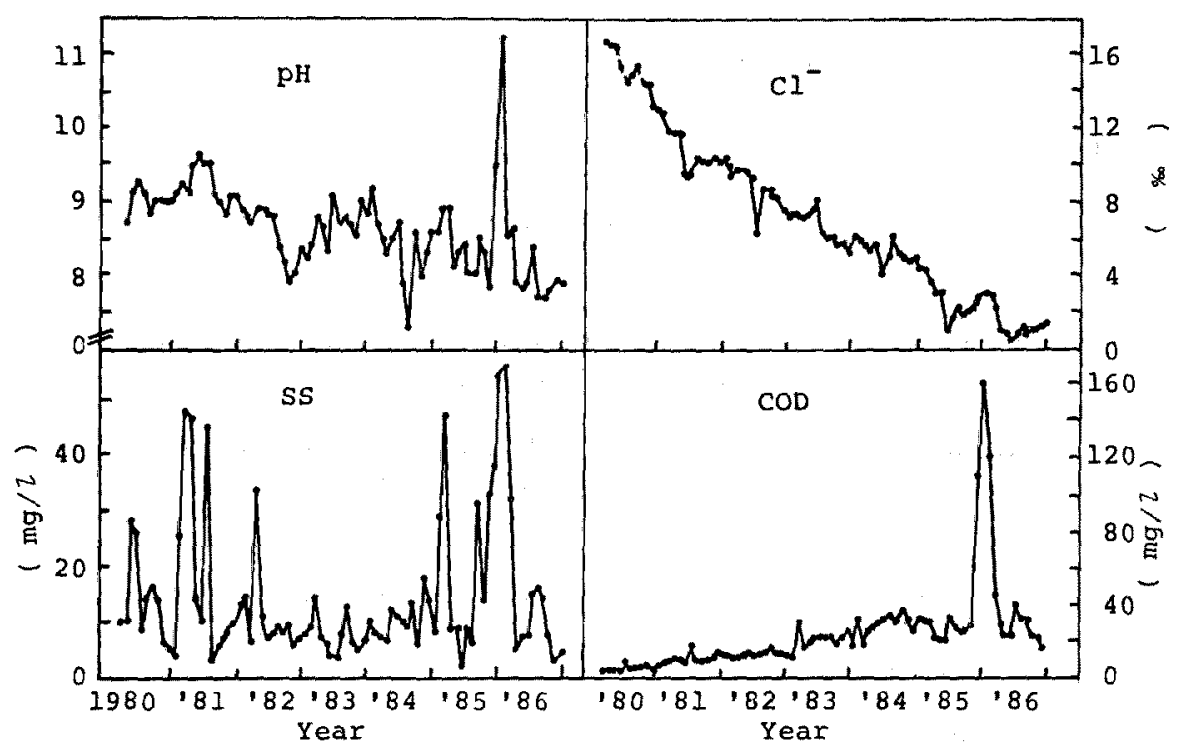

Fig. 1a. Variation of $\mathrm{pH}$, chlorinity $\left(\mathrm{Cl}^{-}\right)$, suspendid solids (SS), and $\mathrm{COD}$ during coastal reclamation.

Bar line, estimated with extrapolation.

$\mathrm{cm}$ 以线）について，1980 年 4 月から測定項目に上って は 1 年あるいは 3 年遅九て測定艺開始し，1987 年 1 月 まで每月 1 回実施した。水温, pH 执上び COD はJIS $\mathrm{K} 0102^{\mathrm{b})}$ ，浮避物質 (プランクトンを含む) 抬ょび総空菜

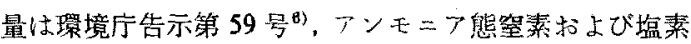
量は下水道試験法》によって行った。このうり，塩素量 估1981 年 4 月から湘定をはじめたので,データの不足 した 1980 年 4 月から 1981 年 3 月の值はそれ以後の 約 6 年間にわたる測定結果を用い，理論的傾向線の式を 算出して外挿して求めた ${ }^{8)}$ 。むた，総窒素量とフンモ二 ア態窒素の 2 項目は他の剆定項目之はことなり，1984年 から年に 4 回ないし 5 回随時測定したが、フンモ二フ 熊窒素は 1986 年以降，測定を実施しなかった。な施， 1983 年 4 月から 1984 年 3 月にわたる一年間, 表層水 と底から $1 \mathrm{~m}$ 上の底層水の 2 試料についてブランクト ンの出現状沇を比較㛟討した結果，成蔡期と呼ばれる季

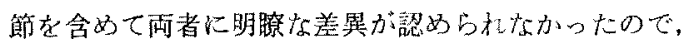
今回の検討には表風水で得られた絬果を用いることとし t。

水質のクラスタ一分析 ${ }^{01}$ は $\mathrm{pH}$, 塩素量, 浮遊物質, 拉 上び CODの 4 項目を用いて，2月，5月，8月，招上 び 11 月の各月の非類似度を標準化ニークリッド平方距 離であらわして，さらに非類似度の小さいるのから順次 階段状につないでもとめた。

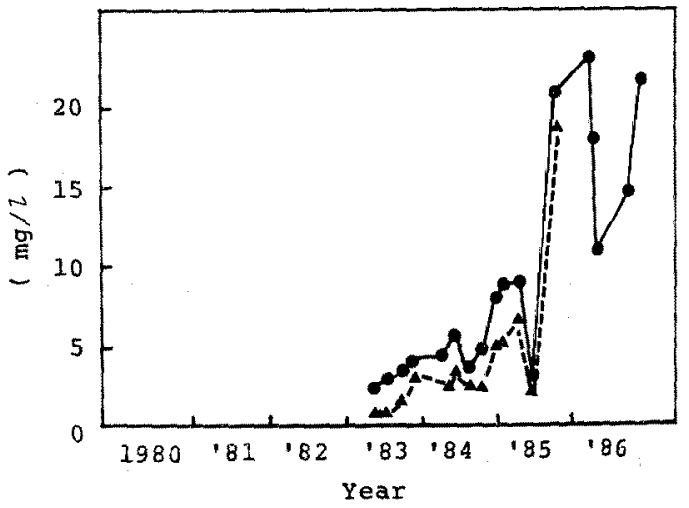

Fig. 1b. Variation of total nitrogen (- - ) and ammonia nitrogen (-- - ) during coastal reclamation.

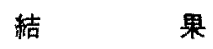

各水柕測定項目の推移 約 7 年間にわたる調查の間, 水温《 6.9 㣻ら $28.9^{\circ} \mathrm{C}$ の間を変動した。Fig. 1a 下示

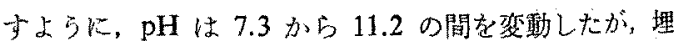
め立ての進行とともに低下の傾向がみられた。塩素量隹, 海面を任切った当初は周边海水の塩菜量 18.4 から 19.1 $\%{ }^{10)}$ ．類似した值であったことが推定される。水質测定 をはじめた 1981 年 4 月に浪，海面を仕切ってわずか1

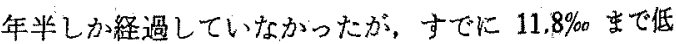
下しており，その後濑次減少し，最低値は $0.5 \%$ であっ た。CODは，はじめ $2 \mathrm{mg} / l$ 前後であったものが埋め立 


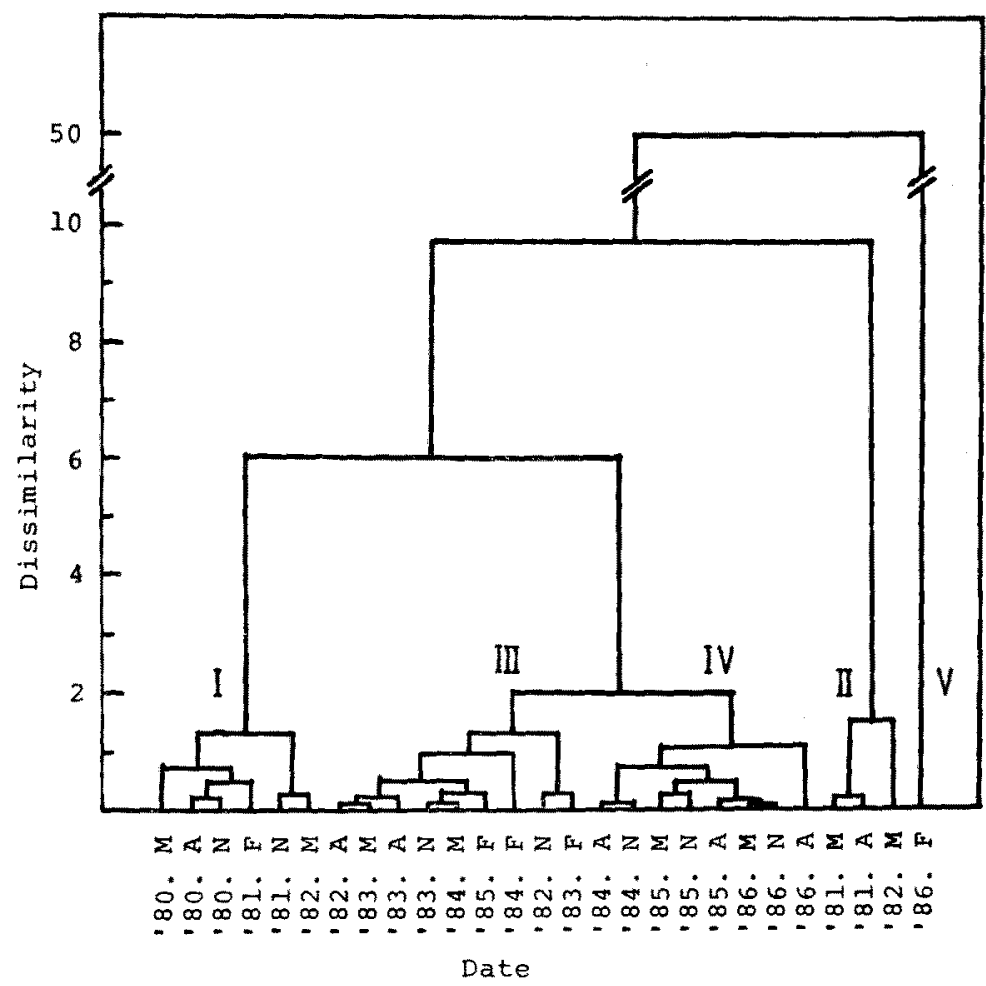

Fig. 2. Dendrogram resulting from linkage of unsimilarity matrices with standardized squared Euclidean distance among 27 samples with four water factors such as pH, chlorinity, suspended solids, and COD during coastal reclamation.

ての進行ととる徐々に增加してい，1985 年 12 月に は35 $\mathrm{mg} / \mathrm{l}$ となり 1986 年 2 月には一時 $160 \mathrm{mg} / \mathrm{l}$ をで 急上昇し，ての後低下して 15 から $45 \mathrm{mg} / l$ ですった。 浮遊物質は 2 力口 $57 \mathrm{mg} / \mathrm{l}$ て，备月每に大与く变動して

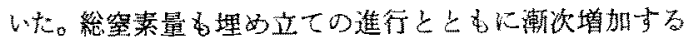
便向が㴓められ，最大值は $23.5 \mathrm{mg} / \mathrm{l}$ であった。このら ち、フンモ二ア熊空素の占める割合名年々增加してゆき 1985 年 11 月には総空菜量の $91 \%$ を占めた (Fig. 1b)。

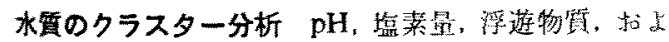

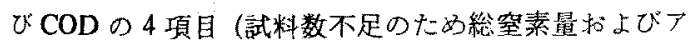
ンモニフ熊窸素量性除いた）を用いてクラスタ一分析を

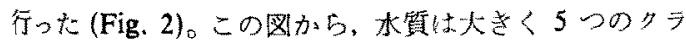
スターに区分されれ。

各々のクラスターの推移状況を Table 1 に示爽。第 I クラスターは，途中に第 IIタラスターをはさんで 1982

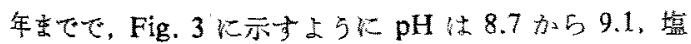

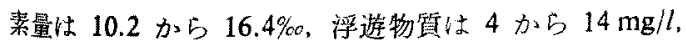

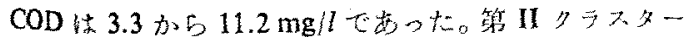
は第Iタラスターにはさ束れた1981 年の5月と8月， 就び第1クラスタ一終了後の1982 年5月と短い期間 であった。このクラスターの $\mathrm{pH}$ 《 8.9 から 9.5 と高 々, 浮游物算は平均 $42 \mathrm{mg} / \mathrm{l}$ と著しく高く，壏素量は第
Table 1. Change of clusters of water quality during coastal reclamation

\begin{tabular}{|c|c|c|c|c|c|c|}
\hline & \multirow{2}{*}{ Date } & \multicolumn{5}{|c|}{ Cluster } \\
\hline & & I & II & III & IV & $\mathrm{V}$ \\
\hline 1980 & $\begin{array}{l}\text { May } \\
\text { August } \\
\text { November }\end{array}$ & 8 & & & & \\
\hline 1981 & $\begin{array}{l}\text { February } \\
\text { May } \\
\text { August } \\
\text { November }\end{array}$ & 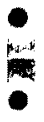 & 8 & & & \\
\hline 1982 & $\begin{array}{l}\text { February } \\
\text { May } \\
\text { August } \\
\text { November }\end{array}$ & - & 0 & & & \\
\hline 1983 & $\begin{array}{l}\text { February } \\
\text { May } \\
\text { August } \\
\text { November }\end{array}$ & & & 8 & & \\
\hline 1984 & $\begin{array}{l}\text { February } \\
\text { May } \\
\text { August } \\
\text { November }\end{array}$ & & & 9 & & \\
\hline 1985 & $\begin{array}{l}\text { February } \\
\text { May } \\
\text { August } \\
\text { November }\end{array}$ & & & & 8 & \\
\hline 1986 & $\begin{array}{l}\text { February } \\
\text { May } \\
\text { August } \\
\text { November }\end{array}$ & & & & 8 & - \\
\hline
\end{tabular}




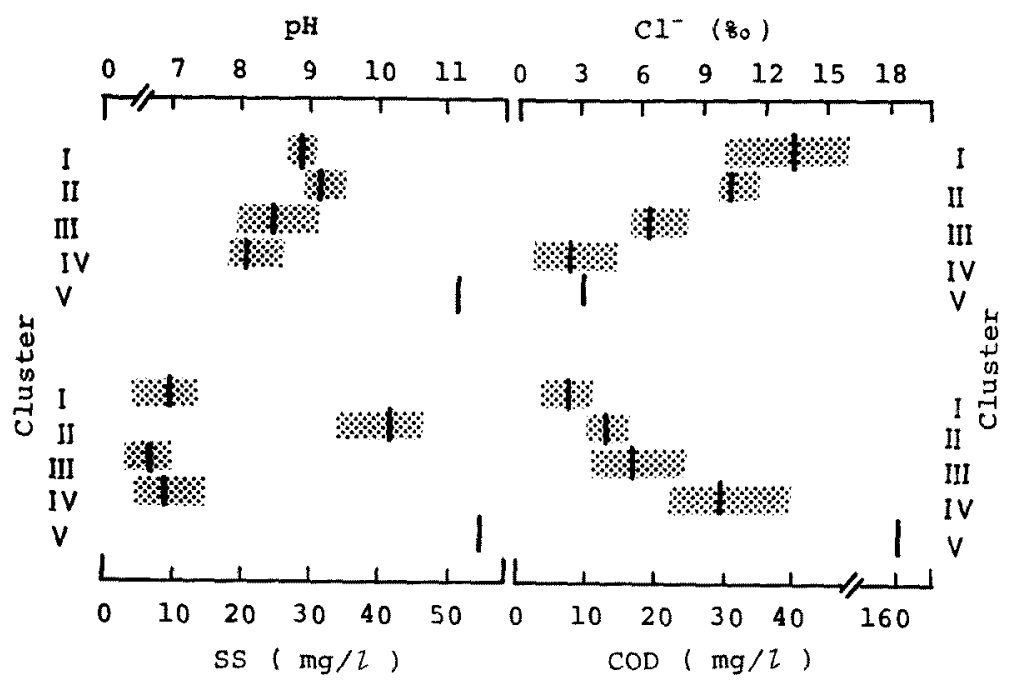

Fig. 3. The range of $\mathrm{pH}$, chlorinity $\left(\mathrm{Cl}^{-}\right)$, suspendid solids (SS), and $\mathrm{COD}$ in each cluster. Bar: Each bar shows the mean value.

Table 2a. Enumeration of dominant bacteria and phytoplankton in each occurrence type obtained from clusters of water quality in the coastal reclamation pond

\begin{tabular}{|c|c|c|c|}
\hline $\begin{array}{c}\text { Occurrence } \\
\text { type* }\end{array}$ & $\begin{array}{c}\text { Bacteria and } \\
\text { phytoplankton }\end{array}$ & $\begin{array}{c}\text { Occurrence } \\
\text { type* }\end{array}$ & $\begin{array}{c}\text { Bacteria and } \\
\text { phytoplankton }\end{array}$ \\
\hline \multirow[t]{5}{*}{1} & Ceratium furca & $1-3$ & Ebria tripartita \\
\hline & $\begin{array}{l}\text { Gymnodinium nagasakiense } \\
\text { Gymno. splendens } \\
\text { Heterocapsa triquetra } \\
\text { Noctiluca miliaris } \\
\text { Pyrophacus steinii }\end{array}$ & $1-2-3-4$ & $\begin{array}{l}\text { Fillamentous bacteria } \\
\text { Cryptophyceae } \\
\text { Cyclotella spp. }\end{array}$ \\
\hline & $\begin{array}{l}\text { Scrippsiella trochoidea } \\
\text { Asterionella glacialis } \\
\text { Cerataulina bergonit } \\
\text { Chaetoceros affine } \\
\text { Chaeto. curvisetum } \\
\text { Chat dehilo }\end{array}$ & 3 & $\begin{array}{l}\text { Coccochloris sp. } \\
\text { Hemiselmis sp. } \\
\text { Skeletonema sp. } 2 \\
\text { Eutreptiella } \mathrm{sp} . \\
\text { Dispora sp. }\end{array}$ \\
\hline & $\begin{array}{l}\text { Chaeto. debile } \\
\text { Chaeto. decipiens } \\
\text { Chaeto. didymum } \\
\text { Chaeto. sociale } \\
\text { Corethron pelagicum }\end{array}$ & $3-4$ & $\begin{array}{l}\text { Pyramimonas spp. } \\
\text { Oocystis sp. } \\
\text { Chlamydomonas sp. }\end{array}$ \\
\hline & $\begin{array}{l}\text { Coscinodicus asteromphalus } \\
\text { Coscino. granii } \\
\text { Guinardia flaccida } \\
\text { Leptocylindrus danicus } \\
\text { Rhizosolenia delicatula } \\
\text { Rhizo. fragilissima } \\
\text { Rhizo. imbricata } \\
\text { Rhizo. setigera } \\
\text { Rhizo. stolterfothii } \\
\text { Streptotheca thamensis }\end{array}$ & 4 & $\begin{array}{l}\text { Oscillatoria spp. } \\
\text { Chroomonas sp. } \\
\text { Cymbella sp. } \\
\text { Gomphonema spp. } \\
\text { Navicula spp. } \\
\text { Nitzschia spp. } \\
\text { Pinnularia spp. } \\
\text { Euglena sp. } \\
\text { Phacus tortus } \\
\text { Chlorella } \mathrm{sp} .1 \\
\text { Chlorella } \mathrm{sp} .2\end{array}$ \\
\hline $1-2$ & $\begin{array}{l}\text { Prorocentrum spp. } \\
\text { Cylindrotheca closterium } \\
\text { Skeletonema costatum }\end{array}$ & & $\begin{array}{l}\text { Eudorina elegans } \\
\text { Ourococcus sp. } \\
\text { Pandorina morum } \\
\text { Scenedesmus spp. }\end{array}$ \\
\hline 2 & Chaetoceros orientale & & $\begin{array}{l}\text { Spondilomorum quaternarium } \\
\text { Wastella sp. }\end{array}$ \\
\hline $1-2-3$ & $\begin{array}{l}\text { Anabaena spiroides var. crassa } \\
\text { Chaetoceros sp. } 1 \\
\text { Chaetoceros sp. } 2 \\
\text { Entomoneis sp. } \\
\text { Skeletonema sp. } 1\end{array}$ & $4-5$ & Thiocapsa roseopersicina \\
\hline
\end{tabular}

* Occurrence type $I$ indicates that appearance of plankton was found only within cluster 1 ; occurrence type 1-2-3 means that plankton appearance extendeds over clusters I, II, and III. 
Table 2b. Enumeration of dominant zooplankton in each occurrence type obtained from clusters of water quality in the coastal reclamation pond

\begin{tabular}{|c|c|c|c|}
\hline $\begin{array}{l}\text { Occurrence } \\
\text { type* }\end{array}$ & Zooplankton & $\begin{array}{c}\text { Occurrence } \\
\text { type* }\end{array}$ & Zooplankton \\
\hline \multirow[t]{4}{*}{1} & $\begin{array}{l}\text { Tintinnopsis beroidea } \\
\text { Tin. kofoidi }\end{array}$ & $1-3$ & Eurytemora sp. \\
\hline & $\begin{array}{l}\text { Tin. radix } \\
\text { Acartia sp. }\end{array}$ & $1-3-4$ & Euplotes spp. \\
\hline & $\begin{array}{l}\text { Euterpina actifrons } \\
\text { Microsetella norvegica }\end{array}$ & 3 & Diaphanosoma brachyurum \\
\hline & $\begin{array}{l}\text { Oithona sp. } \\
\text { Evadne sp. }\end{array}$ & $3-4$ & $\begin{array}{l}\text { Cyclopoida } \\
\text { Sinocalanus tenellus } \\
\text { Moina macropa }\end{array}$ \\
\hline $1-2$ & Halteria sp. & & \\
\hline $1-2-3$ & Mesodinium spp. & 4 & $\begin{array}{l}\text { Paramecium sp. } \\
\text { Brachionus angularis } \\
\text { Bra. calyciflorus }\end{array}$ \\
\hline $1-2-3-4$ & $\begin{array}{l}\text { Cyclidium spp. } \\
\text { Strobilidium spp. } \\
\text { Asplanchna spp. } \\
\text { Brachionus plicatilis }\end{array}$ & & $\begin{array}{l}\text { Bra. rubens } \\
\text { Daphnia longispina } \\
\text { Daph. pulex } \\
\text { Hexarthra mira } \\
\text { Polyarthra trigla }\end{array}$ \\
\hline $1-2-4$ & Didinium ballinanii & & \\
\hline
\end{tabular}

* Same as those in Table 2a.

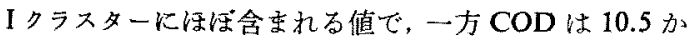
ら $16.6 \mathrm{mg} / l$ でこ机は第 III タラスターに含ま机る值で あった。第IIIクラスターは1982 年 8 月から 1984 年 5 月までの約 2 年間で $\mathrm{pH}$ ，塩素量，特よび浮遊物質は 第 II クラスターでの值上り低くなる傾向が文とめられ たが、COD のみは最高値が $25 \mathrm{mg} / l$ と高くなっていた。 第 IV クラスターは, 1986 年 2 月を除く 1984 年 8 月 から 1986 年 11 月までの約 2 年間で，塩素量は 0.9 か 5 5.0\% と第 III クラスターでの場合より低下し，COD は 22 から $40 \mathrm{mg} / l$ とさら熇くなっていた。第 Vク ラスターは1986 年 2 月の 1 回のみで, $\mathrm{pH} 11.2$, 塩素 量 $3.2 \%$ ，浮遊物質 $55 \mathrm{mg} / l$, COD $160 \mathrm{mg} / l$ で塩素量以 外塂常値を示していた。

水質のクラスター分析結果之細菌類やプランクトンの 出現組成との関保 前報》で示したプランクトン優占種 を本報の Table 1 と対比し，得られた結果を Table 2a， $2 \mathrm{~b}$ K示す。細菌類では, 米状細菌類が第 V タラスタ一 を除く 4 つのクラスターに出現し，一方紅色イオウ細菌 の Thiocapsa roseopersicina が第 IV と第 Vクラスター に出現していた。

植物ブランクトンでは，沿岸，内湾性と四ばれる游痤

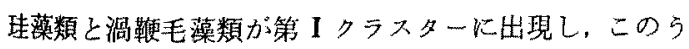
ち多くの珪藻類は1回目の第Iクラスター内で消隇し た。一方, 渦靴毛藻類の数種は 1 回目の第 11 Iラスター の終了時女で出現した。海産珄藻類の Skeletonema costatum 惊第 II クラスターにも出現したが，打もに 1 回
目上2回目の第Iタラスターに多量に出現した。渦鞭毛 藻類の Prorocentrum 属々珪藻類の Cylindrotheca closterium の 2 種は第 $\mathbf{I}$ および第 II クラスターの両方に 出現した。第 II クラスターにのみ出現したのは珪澡類 のChaetoceros orientale 1 種のみであった。2 回目の第 I, 第 II, 姑上び第 III クラスターの3 つのクラスター に出現したのは監藻類の Anabaena spiroides var. crassa, 珪藻類の Chaetoceros 属 2 種, Entomoneis sp. Skeletonema 属 1 種で, Chaetoceros 属 2 種の消隇時 は第 III クラスターの終了時と一致した。第I拉よび第 III クラスターに出現したのはエブリア藻類の Ebria tripartitaのみであった。第 III クラスターにのみ出現した のは珠藻類の Skeletonema 属の 1 種, クリプト藻類の Hemiselmis sp. など 5 種で, このうち 2 種が第 III ク ラスターの終了時まで継続して出現した。第 III クラス ターから第IVクラスターにわたって出現したのはクリ ソ藻類の Pyramimonas 属中緑藻類の Oocystis sp.など, でこれらの出現開始時期は第 III クラスターの開始時と 一致した。第 IVクラスターにのみ出現したのは，緑藻 類のOurococcus sp. Chlorella 属 2 種, 特上び羽状 理藻数の多くの種類で, Ourococcus sp. 惊どは出現開始 時期が第 IVクラスター開始時と一致した。

以上の上らに埋立地内水面㲹出現した糸状細菌，植物 プランクトン 65 種（属レベルでまとめたものる1種と して数えている。亦た，種名の同定できなかったクりプ 卜藻類も 1 種とした）の水質クラスターに対する出現バ 
ターンは若干複雜なものがあった。しかしこれらのうち 出現期間が 1 つのラスターの中に入ってしまうむの や，出現が2つ以上のクラスターにわたったが出現の開 始特期や消隇時期が各クラスターの変吝り目に一致ある いは前後したものは 51 種に挌よんでいた。

動物プランクトンの場合，分類を属，科レさルでまを めたことも影揰して出現期間が長く检討が困難であった が，織毛虫類のうち Tintinnopsis 属㤬第 I クラスターに の及出現し. Paramecium sp.は第 IV クラスターにのみ 出現した。輪蝢のシオミズッボワムシ Brachionus plicatilis のみは，単一種でありながら，第 V クラスターを のぞく 4 つのタラスターのすべてに出現した。一方, 本 種と同じ属の淡水産種B. calyciforus なと3 粨は, 第 IV クラスターにのみ出現していた。

節足動物の暁脚類队枝角類に扣いても Acartia sp., Euterpina actifrons, Microsetella norvegica, Oithona sp., 招よび Evadne sp.などの海産種が第 I クラスター に出現した。汽水廉種の Eurytemora sp. が第 I および 第 III クラスターに. Sinocalanus tenellus が第 III 扰よ び第 IV クラスターに出現し，Daphnia longispina ゃ Daph. pulex 板どの淡水産ミジンュ類 2 種が第 IV クラ スターのみ炕出現した。

\section{考察}

当地の海面埋立地内水面俚，廃乗物の投入に上り方ず か 10 年足らずのらちに急速に陸化した。そのため，本 内水面の水質は塩素量が海水から淡水近くの值まで急激 に低下し，生污濁が著しく進行したといら特殊性が認 められた (Fig. 1)。

この上うに急激な变化をたどる水質も， $\mathrm{pH}$ ，塩素量， 浮遊物質, 招上び COD 04 万の理化学的水質測定值を

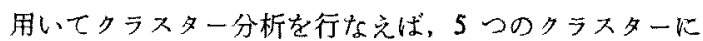
分類することができた（Table 2)。これらクラスターの 塩素量や COD の值之それ艺れのクラスター内に出現し たプランクトンの出現傾向を比較检討すると，Skeletonema costatum 在はしめよする多く海産種が活発に增 殖し消減した第 I クラスターと, 一部の海産種のみが出 現し太第 II クラスターの塩素量の下限值はそれぞれ $10.2 \%$ と $9.7 \%$ であった。また，汽水産珠藻の Chaetoceros orientale が出現した第 II クラスターの8 月の塩 素量は 9.7\%。であった。一方，淡水産種の出現が少られ た第 IV クラスターの塩素量の上限値は 5.0\% であっ た。これらのことから, 本内水面で海産種と汽水産種と が交代した塩素量は 10\% で，5\% 以下からは淡水産種 の出現が可能であることが示唆された。伊藤 ${ }^{11}$ は，趢鰻 用の汽水池の動物ブランクトン調查から，9\% 以上は海 産系，1 力5 $9 \%$ は汽水系，塩素量 $1 \%$ 以下淡水系
が卓越するとし，5\%。以下には一部の淡水系る出現する と報告した。これらの結果は本埋立地内水面の植物プラ ンクトンの出琴バターン亡よく一致している。しかし，

養鰻用の汽水池では Ceratium furca, Ceratium macroceros, Tintinnopsis radix, Favella ehrenbergii, および Oithona nana など 5 種の海産種が塩菜量 5\%。蓑で出現 していだ ${ }^{11}$ が，本埋立地内水面では $10 \%$ までしか出現 しなかったことが異なっている。

COD についてみれば，多くの海麾種が出現できた 第I クラスターの上限值は約 $10 \mathrm{mg} / l$ であり，一部の海 産種が出現できたのは第 II クラスタ一の上限値の 16.6 $\mathrm{mg} / \mathrm{l}$ であった。吉田 $\left.{ }^{12}\right)$ は海域の栄意階級区分で，海産植 物プランクトンの出現が著しく娍少する腐水域の COD は $10 \mathrm{mg} / l$ からとしている。このことから本内水面での 10 から $17 \mathrm{mg} / \mathrm{l}$ といら COD は海産種加汽水産種へ の交代に関与していたと推定される。汽水産乩よび淡水 産プランクトンは第 III 拉よび第 IV クラスターの COD が 20 から $40 \mathrm{mg} / l$ のあいだでもよく增殖した。 第 VクラスターのCOD $160 \mathrm{mg} / \mathrm{l}$ の時は植物拈よび動 物プランクトンが全く観察されず，Thiocapsa roseopersicina よとの細菌類を除きプランクトンの生育には 適していなかったことが示唆された。なお，第 Vクラス ターの $\mathrm{pH}$ は 11.2 と他のクラスターと比べ高かったが, これはこの時植物プランクトンが観察されなかったこと から，赤潮に上る $\mathrm{pH}$ の上昇ではなく，内水面へ投萧処 分された廃葉物の影㗽炕よるるのと考兄られる。

本埋立地内水面化执いて，临一種で第 I から第 IVク ラスターの4つのクラスターに出現したのはシォミズッ ボワムシ Brachionus plicatilis 1 種の多であった。本種 は調查を行った 7 年間にかたって出現したが，12月か ら 3 月の低水温期には出現が認められず、水温によって 出現時期が規制された。しかし，塩素量に対する出現範 囲は 0.5 から 15.4\%, COD では 4.5 から $40 \mathrm{mg} / l, \mathrm{pH}$ では 7.3 から 9.5 とこれらの3 つの環境要因のかなり 広い変化に耐えていた。

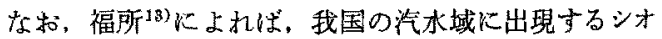
ミズッボワムシは高水温域のみに出現する $\mathrm{S}$ 型と低水 温域にも出現する L 型の 2 型が存在する。また，塩素 量に対しては 0.6 から 7.3\% の範围に出現し，培趪種で は塩素量 $18 \%$ で毛培養可能とされている。 $\mathrm{pH}$ 変化に 奶して注適応籁国が広く, pH 5 から 10 で正常の增殖が みられ，好適範围は $\mathrm{pH} 5$ から 10 と報告されている。 本埋立地内水面のシオミズッボワムシは, $\mathrm{S}$ 型の出現㑯 向を示し，塩素量に対しては高濃度域での出現が可能で， pH に対しては正常增殖を行っていたものと考克られ る。

しかし、シオミズッボワムシを除く多くのブランクト 
ン每占種は4つのクラスターにわだっての出現は認めら れず，1つのクラスター内で出現し消減しているか，あ るいは 2,3のクラスターにわたって出現した。2,3の クラスターにわたって出現した場合は，出現の開始時期 や消减時期が各タラスターの恋わり目に一致するものが 多かった。これらのことから, 理化学的水質要因からみ た本質の数値分類群の推移とブランクトンの出現選移バ ターンには関連のあることが示唆された。

本質の各クラスターの開始期惊，分析汇用いた 2 月， 5 月, 8 月, 扰よび 11 月の 4 つの月のうち， 5 月と 8 月に多かった (Fig. 3)。一方、植物プランクトン䐴占棰 の出現開始時期や消隇時期もこれらクラスタ一の变和り 目の5月と8月に重なることが多かっだ。5 月和よび 8 月水水温の上算叔上び降雨之関連が深いことから, 気 象現象と皮質さらにはプランクトンの生理生態学的特性 との間に関係のあることが推察される。

\section{謝辞}

本研究を行ならにあたり，監藻類や緑藻類の同定を慁 っ大京都大学梅崎 勇先生, 珪藻類数種の同定之與味樑 いご助言を賜った日本大学の高野秀昭先生ならびに光合 成細菌の同定と有益なご助言を賜った長䐀大学松山通郎 先生に感謝の意を表する。また，埋立地内水面のブラン クトン詞料と水質の測定結果を提供して下さった北九州 书摆境事業局施設課の職員の皆样に事心より感謝する。 この研究の実施について愿意あるご配虑いただいた同市 環境衛生研究所の安田英一所長敌よび城戸浩三主幹に深
謝する。

$$
\text { 文献 }
$$

1) M. Yamada, Y. Hanada, A. Miyazaki, A. Tsuruta, and Y. Yoshida: Nippon Suisan Gakkaishi, 56, 00-00 (1990).

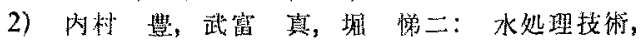
29, 109-114 (1988).

3)内村 基, 石川精一, 穻由和彦: 水处理技術, 29, 365-370 (1988).

4) 石田省三, 缃沢和好：水, 387, 16-23 (1986).

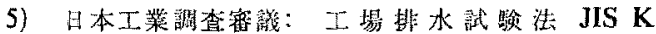
0102，日本規恪堗会，東京，1971，pp. 1-169.

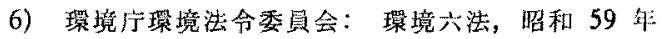
版，中央法規，栥京，1984，pp. 558-606.

7) 日本下水道㹢会：下水試龆法 1974 年版, 日本 下水道增会, 東京, 1977, pp. 119 131, 137-140.

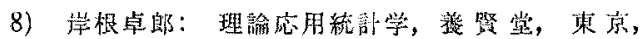
1974, pp. 156-163.

9）奥野忠一，久米 均，芳賀般郎，吉澤 正：多 変量解析法, 日科技連, 東京, 1983, pp. 393400 .

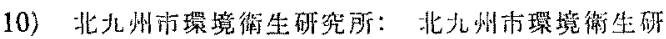
究所瓡(昭和 54 年度)，7，42 (1980)。

11) 伊藤 隆： Rep. Fac. Fish. Mie Pref. Univ., 2, 473-501 (1957).

12）䓃田隄一：漁業環境つセスメン卜（吉田多摩夹 編) 水産学シリーズ 48, 恒星社原生閣, 東京, 1983, pp. 25-46.

13）福所邦彦：シホミズッボワムシー生物学と大量 培養（日本水産学会編）水産学シリーズ 44, 恒 星社厚生閣，東京， 1983，pp. 35-51. 